\title{
Piety Contest of Property Business in Using Sharia Labels
}

\author{
Waldi Nopriansyah ${ }^{1}$, Nova Yanti Maleha ${ }^{2}$, Bagus Setiawan ${ }^{3}$ \\ \{waldi@ stebisigm ${ }^{1}$, nova@ stebisigm $^{2}$, bagus@ stebisigm ${ }^{3}$ \}
}

Sekolah Tinggi Ekonomi Syariah Indo Global Mandiri (STEBIS IGM), Palembang, Indonesia ${ }^{1}$, Sekolah Tinggi Ekonomi Syariah Indo Global Mandiri (STEBIS IGM), Palembang, Indonesia ${ }^{2}$, Sekolah Tinggi

Ekonomi Syariah Indo Global Mandiri (STEBIS IGM), Palembang, Indonesia ${ }^{3}$

\begin{abstract}
The abstract needs to Property entrepreneurs are competing to show the piety side of their business. In showing this piety, what property entrepreneurs do is use the Sharia label as a contestation of piety. The use of the sharia label certainly not only shows the piety of his business but also shows piety for those who own Sharia properties. Besides, owning Sharia property is considered a medium in the process of migrating and purifying oneself. Therefore this article will discuss the contestation of the piety of the property business in the use of the Sharia label as seen from the current phenomenological side. The author will describe the Sharia property from several kinds of literature and then analyze it. The author concludes that the property business that uses the Sharia label has a piety value for its business, whereas for consumers, owning Sharia property does not only show individual piety but also as a form of repentance to God.
\end{abstract}

Keywords: Piety, Property Business, Sharia, Migrate, Self-purification.

\section{Introduction}

It seems that the property business is being intensively carried out by business actors considering that property is the main need for humans as a place to live, Moreover, businesses in the field use the Sharia label. This makes it a contest for property business actors to show the piety of their business. other than that, The uniqueness of the Sharia property business is that it contains spiritual values based on the Qur'an and Hadith as the basic form of this business. With clear sources, the Sharia property business has no room for doubt for consumers who want to have an Islamic home or residence. With a clear source, the Sharia property business has no room for doubt for consumers who want to own an Islamic home or residence.

The needs of the Muslim community who want a cheap, religious house, free of bank interest or usury are the dreams of every community. To answer this dream, Sharia property is considered the answer to their dream. However, the needs of people who want to own a house or residence are sometimes used by people who are not responsible for committing fraudulent crimes, so that crime is always lurking for potential customers to choose property. to avoid evil, hence the Sharia property business is considered as a solution to avoid crime. But recently, Muslims have been shocked by the fake (unclear) Sharia property business, such as the case of the Sharia Property fraud committed by PT. ARM Citra Mulia which harmed 270 victims [1] and the second case was conducted by PT. Wipro Citra Sentosa, which involved 3,680 victims with a loss of 40 billion [2]. The occurrence of these two cases is none other 
than due to consumer interest in buying houses with installments and low prices without interest or usury and also without checking BI checking, Moreover, the property uses Islamic symbols that make consumers sure.

It is inevitable that the use of Islamic symbols in the financial sector, one of which is the sharia label, makes its appeal for Muslims. because the use of the word Sharia will be attached to the piety of a person or business being carried out, as is done by property entrepreneurs to attract the attention of the Indonesian people whose population is Muslim.

People are starting to look for a safer lifestyle by using products and services that are considered halal and also free from usury and bank interest. This kind of lifestyle is starting to be sought by the community, especially those who are Muslim, for example, one of which is having Islamic or sharia housing. The public's desire to own a sharia house can be seen as the Financial Services Authority (OJK) provides a report on the growth of interest in sharia property where the distribution of Islamic mortgage financing grew $19.11 \%$ as of October 2017, This growth will continue, considering that the financing of the Islamic housing sector still has great room to develop [3]. The cause of the growing interest in sharia property is the high number of Muslim residents and the increasing demand for housing [4]. Also, according to Darojatun, the growth of Islamic property financing is none other than the high concern of the public for halal products and it is also free from usury so that it has a positive impact on society in obedience to religious orders, economy, and trade that will prosper the people.[5] Therefore, with the increasing demand for housing, it becomes an opportunity for developers to develop a business or Islamic housing business.

As a result of the growth in demand for Islamic homes, this has led to the emergence of the Islamization of other products. The use of Islamic financial products is a trend (lifestyle) today. This is because the use of Islamic financial products is claimed as a religious identity and will show it as a side of one's piety or religiosity [6]. The lifestyle towards the use of Islamic financial products is then warmly welcomed by middle-class Muslims in particular because, for the Muslim view, someone who does not use Islamic products is considered not part of the middle-class society [5].

The emergence of Sharia property businesses is not only claimed to defend Muslim identity or as a claim of piety, but there are indications in it that the Sharia property business is a way of responding to changes that occur in the world, be it changes that come from social, economic to political.

\section{Literature Review}

The study concerning Sharia property is not new, but something is interesting about this research, especially regarding the use of the Sharia label in business or business as a contestation of piety, therefore the literature review will review previous reviews carried out with a relevant approach.

Research disclosed by Warner states that Islamic finance is claimed to be sacred finance and everyone must invest in Islamic financial instruments [7]. This claim makes businesses in the field of Islamic property very attractive as expressed by Sihotang et al that entrepreneurs are starting to compete to open Sharia property businesses [4].

According to Darojatun, the use of the Sharia label in financial products is a form of playing psychologically to consumers to create a classification that makes consumers submit to the criteria they set [5]. What was revealed by Darojatun, then supported by Muali and Nisa who revealed that the use of the Sharia label is a Sharia marketing strategy that has the concept of profit and blessing [8]. 


\section{Methods}

\subsection{Type of Research}

This type of research is qualitative research supported by secondary data. Other supporting data is also obtained from the results of a review of research on Islamic property, and data can come from the relationship between piety contestation of Islamic financial products.

\subsection{Research Approach}

This research approach uses a phenomenological approach. That is, the researcher examines the current phenomenon in the use of the Sharia label in financial products.

\subsection{Data analysis}

There are two details that the researcher does in analyzing the data, namely, first, the researcher analyzes the data by explaining the piety that occurs in the Islamic property business, the second the researcher analyzes about for users of Islamic property. In this analysis, the researcher sees an impact on the presence of Sharia property. This impact is believed that the Sharia label has an influence on the piety identity of the property business and also for its users.

\section{Results and Discussion}

\subsection{Promoting the piety of Sharia Property Business in the Sharia Financial Room}

Piety can be defined as pious deeds, which according to Nurcholis etymologically the word pious deeds means acts, jobs, and activities that have good values to generate rewards for the perpetrators, while terminologically the word righteous deeds are all actions that are done consciously and deliberately based on thoughts and dhikr [7].

A phenomenal that is happening at this time is the number of businesses or businesses wanting to show their godly side by using the Sharia label. According to Otto in his book "Sharia and National Law in Muslim Countries: Tensions and Opportunities for Dutch and EU Foreign Policy" for Muslims the use of Sharia is considered a force that will bring improvement.[9] What was expressed by Otto made the sharia the eternal and eternal will of God for mankind? Therefore, today many businesses or business activities use the word sharia as a process of improvement from worldly to ukrawi.

Property business actors in running their business wheels are not only limited to the desire to get profit (profit), but the promotions carried out have educational values that lead to the spiritual side of marketing (Sharia marketing). The example that shows spiritual marketing with a high level of religiosity can be seen in how the promotion or marketing carried out by property entrepreneurs through social media, one of which is using Instagram. These promotions use slogans that have spiritual values such as:

"bring your property to Jannah"

"Riba-free Halal house"

"father and mother provide shelter for their beloved family which is cool not only in this world but for good in the hereafter".

( Instagram: @shofamarwahrealty \& @ propertipalembangsyariah). 
The words "bring your property to Jannah" and " Riba-free Halal house " means that what is obtained and how to get it, then there will be a responsibility towards Allah SWT with what we have achieved and what we already have.

Also, the sentence "father and mother provide shelter for your beloved family that is cool not only in the world but for good in the hereafter.". Contains a deep philosophical value that parents, especially a father who has a heavy-duty in providing for his family's needs, must give their best because the income provided by him will have an impact on all his families, both his wife and children, so that giving the best for the family is an open door goodness in the hereafter. What is unique is that the sentences or slogans used are provocative but have positive values such as "Borrow 100 million, get 90 million, when you return up to 200 million: that's cruel usury".

This is a form of property piety that is presented through social media by entrepreneurs using slogans or words that have spiritual marketing value. Piety itself is in the form of having total submission to Allah SWT in its business. This form of surrender is to get the pleasure of Allah SWT in all economic activities or to make muamalat so that the desire to enter heaven is achieved by applying Islamic values.

\subsection{Sharia Properties: Hijrah and Purification}

For consumers, having Sharia property is a way of life for today's society. The number of sharia property businesses cannot be separated from the existence of popular Islam that has developed among middle-class Muslims. Owning property based on sharia is not only limited to religious orders but is also considered a process of migration and purification of oneself from the use of conventional products which are considered far from the word halal. Hijrah itself is a movement from one place to another that is better. Meanwhile, self-purification can be interpreted as releasing from all forms of actions that are prohibited by God by doing good and performing good deeds as a form of repentance that has been done so far. The phenomenon of hijrah and self-purification is a trend nowadays, especially among the urban Muslim middle class, we can see this around us, be it friends or family. Because the characteristics of the hijrah behavior shown by middle-class Muslims are what they consume. The middle-class Muslim community is indeed the main actor and at the same time the key to the changes that occur in Indonesia, especially those related to economic and social change. On the other hand, the Muslim middle-class community also needs to be careful in making life changes or the hijrah process so as not to fall into radical understandings. Because the Muslim middle-class society is an easy target for radicalizes to indoctrinate their thoughts.

An interesting phenomenon at this time is shown by the middle-class Popular Islam circles, where ownership of Sharia property, then halal products, and the star's lifestyle have become demands in human life so that their acts of worship can be accepted in the hereafter and also to strengthen symbols. the piety that is in him. This symbol of piety is aimed at what Muslims wear, such as star's clothing, transacting with Sharia banks, residing in Sharia residences or houses, and wearing halal products in their daily life [5].

People who choose sharia housing are not only limited to the issue of facilities and infrastructure for worship but also get comfort if they live with people of the same religion. Also, people owning a Sharia house or Sharia property is a form to avoid all sins prohibited by their Lord. Because property or houses offered by conventional parties are considered a way of accumulating sins, because property or houses that are not based on Sharia principles contain usury, while usury is haram.

The behavior carried out by middle-class Muslims by using Islamic products, be it food products, clothing products, Islamic financial products, and other products does not show a 
correlation in the measure of piety as expressed by Pepinsky that the use of these products can be said to be hijrah and penance or purification of oneself but this does not make a measure of one's piety. [6] The use of Islamic products is a way of expressing Islam in increasing piety which is reflected through public activities. This expression shows how Islam fulfills the needs of consumers in Indonesia as a living religion. Although the use of Islamic products is not a measure of piety, the use of Islamic products is an adjustment to religious piety in a modern lifestyle.

\section{Conclusion}

The use of the Sharia label in the property sector has always been a special attraction, especially for Muslims. The Sharia label that is used in every business or business is not only a material for a promotional strategy in attracting the sympathy of the crowd, but the Sharia label will have a spiritual value that creates a space of piety both for its business and for consumers. For entrepreneurs, running a Sharia property is not only about getting profit but also aims to get the blessings and pleasure of Allah SWT. As for consumers, owning Sharia property is a medium between humans and God in the process of migration and selfpurification.

\section{Reference}

[1] "Penipuan Properti Syariah, YLKI: Cabut Izin Usaha Pengembangnya." [Online]. Available: https://properti.kompas.com/read/2019/12/04/144156321/penipuan-properti-syariah-ylki-cabutizin-usaha-pengembangnya. [Accessed: 19-Jan-2020].

[2] "Polisi Buru Dua Pelaku Penipuan Perumahan Syariah Fiktif - VIVAnews." [Online]. Available: https://www.vivanews.com/berita/kriminal/25295-polisi-buru-dua-pelaku-penipuan-perumahansyariah-fiktif?medium=autonext. [Accessed: 19-Jan-2020].

[3]“Laporan Perkembangan Keuangan Syariah Indonesia 2018.” [Online]. Available: https://www.ojk.go.id/id/kanal/syariah/data-dan-statistik/laporan-perkembangan-keuangan-syariahindonesia/Pages/2018.aspx. [Accessed: 03-Mar-2020].

[4] M. K. Sihotang, U. Hasanah, and H. Al Amin, "Pengaruh Religi Dan Harga Terhadap Permintaan Perumahan Syariah Di Kota Medan,” J. Ekon. dan Bisnis, vol. 20, no. 2, pp. 93-105, 2018.

[5] R. Darojatun, "Tren Produk Halal, Gaya Hidup Syar'i Dan Kesalehan Simbolik: Studi Tentang Muslim Kelas Menengah,” J. Wardah, vol. 19, no. 2, pp. 135-157, 2018.

[6] T. B. Pepinsky, "Development, Social Change, and Islamic Finance in Contemporary Indonesia," World Dev., vol. 41, no. 1, pp. 157-167, 2013.

[7] B. Warner, Sharia Law for the Non-Muslim, vol. 8.31.10. USA: CSPI Publishing, 2010.

[8] C. Muali and K. Nisa, "Pemasaran Syariah Berbantuan Media Sosial: Kontestasi Strategis Peningkatan Daya Jual," An-Nisbah J. Ekon. Syariah, vol. 05, no. 2, pp. 168-185, 2019.

[9] J. M. Otto, Sharia and National Law in Muslim Countries: Tensions and Opportunities for Dutch and EU Foreign Policy. Leiden: Leiden University Press, 2008. 